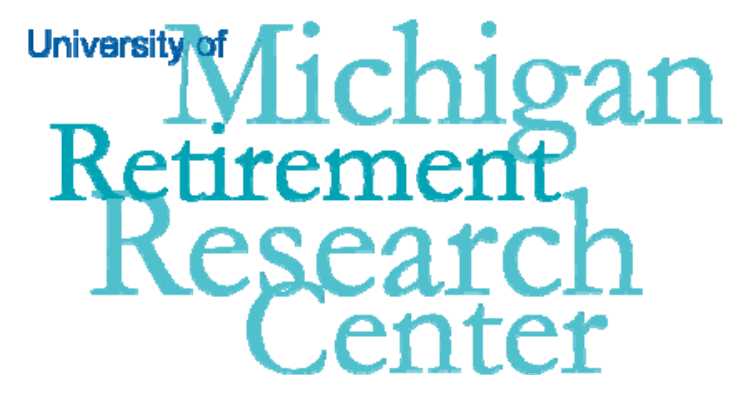

Working Paper

WP 2010-221

\title{
Borrowing from Yourself: The Determinants of 401(k) Loan Patterns
}

Timothy Jun Lu and Olivia S. Mitchell

\begin{tabular}{|l|l|}
\hline $\mathrm{M}$ & $\mathrm{R}$ \\
\hline $\mathrm{R}$ & $\mathrm{C}$ \\
\hline
\end{tabular}$\quad$ Project \#: UM10-10 


\title{
Borrowing from Yourself: The Determinants of 401(k) Loan Patterns
}

\author{
Timothy Jun Lu \\ The Wharton School \\ Olivia S. Mitchell \\ The Wharton School \\ September 2010 \\ Michigan Retirement Research Center \\ University of Michigan \\ P.O. Box 1248 \\ Ann Arbor, MI 48104 \\ http://www.mrrc.isr.umich.edu/ \\ (734) 615-0422
}

\section{Acknowledgements}

This work was supported by a grant from the Social Security Administration through the Michigan Retirement Research Center (Grant \# 10-M-98362-5-01). The findings and conclusions expressed are solely those of the author and do not represent the views of the Social Security Administration, any agency of the Federal government, or the Michigan Retirement Research Center.

\section{Regents of the University of Michigan}

Julia Donovan Darrow, Ann Arbor; Laurence B. Deitch, Bingham Farms; Denise Ilitch, Bingham Farms; Olivia P. Maynard, Goodrich; Andrea Fischer Newman, Ann Arbor; Andrew C. Richner, Grosse Pointe Park; S. Martin Taylor, Gross Pointe Farms; Katherine E. White, Ann Arbor; Mary Sue Coleman, ex officio 


\title{
Borrowing from Yourself: The Determinants of 401(k) Loan Patterns
}

\begin{abstract}
This paper explores the determinants of people's decisions to take 401(k) loans. We argue that 401(k) plans do not simply represent retirement saving, but they also provide a means of saving for precautionary purposes. We model factors that rationally would induce people to borrow from their pension plans, and we explain why people do not often use 401(k) loans to replace their more expensive credit card debt. Next we test our hypotheses using a rich dataset and show that people who are liquidity-constrained are more likely to have plan loans, while the better-off take larger loans when they do borrow. Plan characteristics such as the number of loans allowed also influence borrowing and loan size in interesting ways, while loan interest rates have only a small impact.
\end{abstract}

\section{Authors’ Acknowledgements}

The authors thank Abba Krieger, Gary Mottola, William Nessmith, Greg Nini, Ning Tang, Steve Utkus, Jean Young, and seminar participants at the Department of Insurance and Risk Management of the Wharton School for helpful comments. They are also grateful to Vanguard for the provision of recordkeeping data under restricted access conditions; to the Pension Research Council at the Wharton School, the Bradley Foundation and TRIO Pilot Project Competition for generous research support. The research reported herein was performed pursuant to a grant from the U.S. Social Security Administration (SSA) funded as part of the Retirement Research Consortium. The opinions and conclusions expressed herein are solely those of the authors and do not represent the opinions or policy of SSA, any agency of the Federal Government, The Wharton School, Vanguard, or any other institution with which the authors may be affiliated. (C2010 Lu and Mitchell. 


\section{Borrowing from Yourself: The Determinants of 401(k) Loan Patterns}

More than 62 million US private sector workers are covered by defined contribution (DC) plans, and these plans hold over $\$ 2.8$ trillion in assets (U.S. Dept. of Labor 2007). A majority of these plans permit participants to take a loan from their plans: for instance, $85 \%$ of all participants were in plans that offered loans in 2006 (Vanderhei and Holden 2007). Plan loans allow participants to tap into their savings before retirement. By law, participants may borrow up to half their account balance, currently capped at $\$ 50,000$. They do not need to pay income tax or other penalties as long as they repay on time, and the interest goes to their own accounts. But if a loan taker leaves his job, he is required to pay back all of the remaining loan balance within 60 days. If he fails to do so, the loan is considered to have defaulted, and he must pay income tax plus a $10 \%$ penalty tax on the balance outstanding. Furthermore, those who borrow from their 401(k)s may end up contributing less to their pension accounts after taking the loans, which could reduce their retirement account balances in the long run. With the recent economic downturn, there are also concerns that $401(\mathrm{k})$ loans might be climbing due to participants' inability to obtain other forms of credit. For all of these reasons, plan sponsors and policymakers have expressed increasing interest in learning whether 401(k) loans are sensible in the pension context.

In this research, we explore the factors that affect peoples' decisions to take 401(k) loans. We construct a two-period utility maximization model to compare borrowing from 401(k) accounts and from credit cards. We predict that lower 401(k) loan interest rates, lower expected investment returns during the loan period, and higher credit card interest rates, are likely to 
make taking 401(k) loans more appealing. We also discuss a puzzle identified by Li and Smith (2008) that people do not use 401(k) loans to pay off more expensive credit card debts.

We then investigate the empirical determinants of borrowing from $401(\mathrm{k})$ pension plans. In particular, we assess how employee and plan characteristics affect the propensity to take these loans, and how large the loans are when people take them. First, we find that people who are liquidity-constrained are more likely to have 401(k) loans, but conditional on borrowing, the less-liquidity constrained take larger loans. We also find an inverted U-shape by age for plan borrowing and loan size. If the plan sponsor permits workers to take more loans, this boosts the probability of plan borrowing and loan size, but higher interest rates deter borrowing. These patterns are consistent with our model's predictions and other empirical findings.

In what follows, we first review previous literature. Next we lay out a utilitymaximization model where taking $401(\mathrm{k})$ loans is an option. Subsequently, we introduce our dataset and draw out hypotheses for the determinants of $401(\mathrm{k})$ borrowing. We then show how demographic and plan characteristics affect loan probabilities and link these findings to our hypotheses, followed by an assessment of loan amounts. We close with a brief conclusion.

\section{Related Studies}

Previous research has mostly focused on the impact of pension plan design on participant behavior. Using a sample of 401(k) plans administered by Vanguard, Mitchell, Utkus and Yang (2005) found that higher employer match rates enhance participation rates of lower-paid employees, but they do not increase saving rates very much. Using a smaller sample of plans provided by Hewitt Associates, Madrian and Shea (2001) found that automatic enrollment significantly increases participation rates, and that a large portion of participants under automatic 
enrollment stays with the default contribution rate and default fund allocation. ${ }^{1}$ Nevertheless, few studies have examined the reasons that plan sponsors elect particular plan design features, and fewer still investigate whether providing loans enhances employee participation and contribution rates. Using cross-sectional firm-level data, the General Accounting Office (GAO 1997) reported that participation rates were 6 percent higher in plans that offer loans compared to plans without loan provisions. That study also noted that average annual participant contributions were 35 percent higher in plans with loan provisions than in others. In a much larger study of Vanguardadministered plans, Mitchell, Utkus and Yang (2007) showed that having a loan provision raises contribution rates by about 10 percent. Participant-level data were also examined by Munnell, Sunden and Taylor (2000) and Holden and Vanderhei (2001), who reported that contribution rates were slightly positively associated with having plan loans.

The literature has been relatively silent on the question of who takes loans from their pension plans and what drives this behavior. Vanderhei and Holden (2007) offered descriptive statistics on 401(k) borrowers. Sunden and Surette (2000) reported that people who accumulate higher wealth in their accounts were also more likely to borrow; these individuals were also more likely to have lower financial assets and higher debts and be more credit-constrained. Some analysts have explored how borrowing from the pension accounts might affect aggregate retirement accumulations. The General Accounting Office (GAO 1997) report mentioned earlier suggested that taking loans could result in a loss of retirement wealth; nonetheless, that paper assumed a fixed annual rate of return on pension accounts and a fixed borrowing period, neither of which is realistic. Reeves and Villarreal (2008) stated that the opportunity cost of borrowing $\$ 30,000$ from one's pension account could be as high as $\$ 600,000$, but they assumed that people

\footnotetext{
${ }^{1}$ Other related studies include Choi, Laibson, Madrian and Metrick (2001), Mitchell, Mottola, Utkus and Yamaguchi (2006), Agnew, Balduzzi and Sunden (2003), and Ameriks and Zeldes (2004).
} 
stopped contributing to their accounts during the repayment period. Whether this is realistic or not is unknown. On the other hand, Li and Smith (2008) found that many people carry relatively expensive credit card debt, which they argued was puzzling since participants could have borrowed from their 401(k) accounts at lower rates. That study also concluded that liquidityconstrained households are more likely to take $401(\mathrm{k})$ loans.

In a related but separate literature, Ayres and Nablebuff (2008) show, using a life cycle formulation, that it is optimal for young people to buy stocks on margin. This might provide an incentive for younger people to take loans from their pension accounts. Using CEX data on vehicle loans, Stephens (2008) found that young people are quite liquidity-constrained; this could also motivate taking pension plan loans.

In the analysis that follows, and in contrast to most of the previous literature, we undertake a participant-level analysis of 401(k) plan borrowing. We first outline a simple economic model that illustrates some of the key determinants that affect who and why people might borrow from their 401(k) accounts. We then use a large dataset from Vanguard to empirically test a series of hypotheses regarding the determinants of plan loans, the size of the loans, and proportion of the account balance borrowed. To differentiate our work from previous studies, we look at $401(\mathrm{k})$ assets not only as retirement saving but also as precautionary saving to cover negative income or consumption shocks. We extend Li and Smith (2008)'s work by constructing a lifetime utility maximization model and compare the difference between borrowing from one's 401(k) account versus one's credit card. We integrate a precautionary motive in the form of a buffer-stock (Deaton 1991; Carroll 1997; Ludvigson 1999) where workers may wish to borrow less than all the funds available. Our empirical results support the 
model's predictions nicely and are consistent with research predicting a hump-shaped consumption profile with age (Gourinchas and Parker 2002; Browning and Crossley 2001).

\section{Borrowing from a 401(k) Plan}

Suppose a worker is a $401(\mathrm{k})$ plan participant who receives a demand shock of $\$ x$ at time 0 . She has $\$ B_{0}$ in her $401(\mathrm{k})$ account which she could borrow at interest rate $r_{l}$. She could also choose to take a credit card loan with interest rate $r_{c}$. After she makes her choice, there is an immediate probability of $P_{q}$ that she will leave her job. If she has a 401(k) loan outstanding, she will need to either take a credit card loan immediately to repay the 401(k) loan, or default. In

period 1 , she will have income $w_{s}$ if she stays at her job, or $w_{q}$ otherwise. She will need to repay her debt if it has not already defaulted. We also assume she can save her income in her 401(k) account. Her original employer matches $\$ m_{s}$ for each dollar of contribution; if she changes jobs, her new employer will have a match rate of $\$ m_{q}$. At time 2, the participant retires and consumes all her saving after paying income tax.

Suppose that the expected return rate of investment is $\tilde{r}_{1}$ in period 1 , and $\tilde{r}_{2}$ in period 2 , while the income tax rate is $\tau$ in both periods. The participant's problem is to maximize her utility of consumption. To analyze this problem in more detail, we first consider the case where the participant remains on her job. In this case, she must simply compare the difference in utility resulting from taking a 401(k) loan and a credit card loan. If she chooses to take a 401(k) loan, her problem is

$$
\max _{B_{s}} u\left(c_{l s 1}\right)+\beta u\left(c_{l s 2}\right)
$$

where $c_{l s 1}=(1-\tau)\left(w_{s}-B_{s}\right)-\left(1+r_{l}\right) x$; 


$$
\begin{aligned}
& c_{l s 2}=(1-\tau)\left[\left(1+\tilde{r_{1}}\right)\left(1+\tilde{r_{2}}\right)\left(B_{0}-x\right)+\left(1+\tilde{r_{2}}\right)\left(1+r_{l}\right) x+\left(1+\tilde{r}_{2}\right)\left(1+m_{s}\right) B_{s}\right] \\
& 0 \leq B_{s} \leq \bar{B}_{s} ; c_{l s 1} \geq 0 ; c_{l s 2} \geq 0 ; 0 \leq \beta \leq 1 .
\end{aligned}
$$

Here $c_{l s 1}$ and $c_{l s 2}$ are her consumption at time 1 and time 2 if she takes the 401(k) loan and remains on the old job; $B_{s}$ is her contribution to her $401(\mathrm{k})$ account at time 1 , while $\bar{B}_{s}$ is the maximum contribution allowed by the plan; $\beta$ is her discount rate. The participant chooses $B_{s}$ to maximize her utility. Of course, here we assume that $(1-\tau) w_{s}-\left(1+r_{l}\right) x>0$ so that both $c_{l s 1}$ and $c_{l s 2}$ will be positive.

Conversely, if she chooses to take a credit card loan, her problem is

$$
\max _{B_{s}^{\prime}} u\left(c_{c s 1}\right)+\beta u\left(c_{c s 2}\right)
$$

where $c_{c s 1}=(1-\tau)\left(w_{s}-B_{s}^{\prime}\right)-\left(1+r_{c}\right) x$;

$$
\begin{aligned}
& c_{c s 2}=(1-\tau)\left[\left(1+\tilde{r_{1}}\right)\left(1+\tilde{r}_{2}\right) B_{0}+\left(1+\tilde{r_{2}}\right)\left(1+m_{s}\right) B_{s}^{\prime}\right] \\
& 0 \leq B_{s}^{\prime} \leq \bar{B}_{s} ; c_{c s 1} \geq 0 ; c_{c s 2} \geq 0 ; 0 \leq \beta \leq 1 .
\end{aligned}
$$

Here $c_{c s 1}$ and $c_{c s 2}$ are her consumption levels at time 1 and time 2 if she takes the credit card loan and remains employed. $B_{s}^{\prime}$ is her contribution to her $401(\mathrm{k})$ account at time 1.

It is easy to show that if $B_{s}$ and $B_{s}^{\prime}$ are not binding, then $u^{\prime}\left(c_{l s 1}\right) / u^{\prime}\left(c_{l s 2}\right)=u^{\prime}\left(c_{c s 1}\right) / u^{\prime}\left(c_{c s 2}\right)=\beta\left(1+\tilde{r}_{2}\right)\left(1+m_{s}\right)$, which means that if one option is better than another, the participant would be better off in both periods if she chooses the better option. The utility difference between taking $401(\mathrm{k})$ loan and credit card loan is loandiff $=u\left(c^{*}{ }_{l s 1}\right)+\beta u\left(c^{*}{ }_{l s 2}\right)-u\left(c^{*}{ }_{c s 1}\right)-\beta u\left(c^{*}{ }_{c s 2}\right)$. 
Next we explore the effects of some key variables on the utility difference. For instance, we find dloandiff $/ \partial r_{c}=x \cdot u^{\prime}\left(c_{c s 1}\right)>0$, meaning that the advantage of taking the $401(\mathrm{k})$ loan will be larger if the credit card rate is higher. Also Dloandiff $/ \partial r_{l}=x\left[\beta(1-\tau)\left(1+\tilde{r}_{2}\right) u^{\prime}\left(c_{l s 2}\right)-u^{\prime}\left(c_{l s 1}\right)\right]$. We already showed that under the non-binding situation, $u^{\prime}\left(c_{l s 1}\right) / u^{\prime}\left(c_{l s 2}\right)=\beta\left(1+\tilde{r}_{2}\right)\left(1+m_{s}\right)$, hence we have dloandiff $/ \partial r_{l}=x \beta\left(1+\tilde{r}_{2}\right) u^{\prime}\left(c_{l s 2}\right)\left(-\tau-m_{s}\right)<0$, which means that the advantage of taking a $401(\mathrm{k})$ loan will be larger if the interest rate on the $401(\mathrm{k})$ loan is lower. If $B_{s}$ is lower bounded, i.e. $B_{s}{ }^{*}=0$, then we have $u^{\prime}\left(c_{l s 1}\right) / u^{\prime}\left(c_{l s 2}\right) \geq \beta\left(1+\tilde{r}_{2}\right)\left(1+m_{s}\right)$, hence dloandiff / $\partial r_{l}<0$ still holds. The only possible situation for dloandiff $/ \partial r_{l}>0$ is when $B_{s}{ }^{*}=\bar{B}_{s}$, i.e. the participant is constrained by the maximum contribution amount. In this case she may be better off if the interest rate of the loan is higher; if Dloandiff $/ \partial \tilde{r}_{1}=\beta(1-\tau)\left(1+\tilde{r}_{2}\right)\left[B_{0}\left\{u^{\prime}\left(c_{l s 2}\right)-u^{\prime}\left(c_{c s 2}\right)\right\}-x \cdot u^{\prime}\left(c_{l s 2}\right)\right]$, the effect is ambiguous. But in the case that $c_{l s 2} \geq c_{c s 2}$, the effect is negative, which suggests that a higher expected investment return in the first period reduces the benefit of taking the 401(k) loan. We could further argue that even if $c_{l s 2}<C_{c s 2}$, the effect could still be negative if the consumption difference is relatively small, or the loan amount is relatively large.

Next we look at the case where the participant must change jobs just after taking the 401(k) loan. Note that she can either repay the loan immediately by taking a credit card loan, or she can default and pay income tax plus 10 percent penalty tax on the loan amount. Therefore, we only need to check the difference between defaulting on a 401(k) loan and taking a credit 
card loan. If she takes a 401(k) loan, changes job, and defaults on the loan, her problem is

$$
\max _{B_{q}} u\left(c_{l q 1}\right)+\beta u\left(c_{l q 2}\right)
$$

where

$$
\begin{aligned}
& c_{l q 1}=(1-\tau)\left(w_{q}-B_{q}\right) ; \\
& c_{l q 2}=(1-\tau)\left[\left(1+\tilde{r}_{1}\right)\left(1+\tilde{r_{2}}\right)\left\{B_{0}-(1.1+\tau) x\right\}+\left(1+\tilde{r_{2}}\right)\left(1+m_{q}\right) B_{q}\right] \\
& 0 \leq B_{q} \leq \bar{B}_{q} ; c_{l q 1} \geq 0 ; c_{l q 2} \geq 0 ; 0 \leq \beta \leq 1 .
\end{aligned}
$$

Here, $c_{l q 1}$ and $c_{l q 2}$ are her consumptions at time 1 and time 2 , while $B_{q}$ is her contribution to her new $401(\mathrm{k})$ account, and $\bar{B}_{q}$ is the maximum contribution allowed by her new plan.

Similarly, if she takes a credit card loan, whether it is before or after her job change, her problem is $\max _{B_{q}^{\prime}} u\left(c_{c q 1}\right)+\beta u\left(c_{c q 2}\right)$ where

$$
\begin{aligned}
& c_{c q 1}=(1-\tau)\left(w_{q}-B_{q}^{\prime}\right)-\left(1+r_{c}\right) x ; \\
& c_{c q 2}=(1-\tau)\left[\left(1+\tilde{r}_{1}\right)\left(1+\tilde{r}_{2}\right) B_{0}+\left(1+\tilde{r}_{2}\right)\left(1+m_{q}\right) B_{q}^{\prime}\right] \\
& 0 \leq B_{q}^{\prime} \leq \bar{B}_{q} ; c_{c q 1} \geq 0 ; c_{c q 2} \geq 0 ; 0 \leq \beta \leq 1 .
\end{aligned}
$$

Here $c_{c q 1}$ and $c_{c q 2}$ are consumption at time 1 and time 2 , while $B_{q}^{\prime}$ is her contribution to her new 401(k) account.

Similar to when the participant stays at her job, here we have the utility difference between defaulting on a 401(k) loan and taking a credit card loan as:

loandiff $=u\left(c^{*}{ }_{l q 1}\right)+\beta u\left(c^{*}{ }_{l q 2}\right)-u\left(c^{*}{ }_{c q 1}\right)-\beta u\left(c^{*}{ }_{c q 2}\right)$. With this we can easily derive the following: oloandiff $/ \partial r_{c}=x \cdot u^{\prime}\left(c_{c q 1}\right)>0$; and Dloandiff $/ \partial \tilde{r}_{1}=\beta(1-\tau)\left(1+\tilde{r}_{2}\right)\left[B_{0}\left\{u^{\prime}\left(c_{l q 2}\right)-u^{\prime}\left(c_{c q 2}\right)\right\}-(1.1+\tau) x \cdot u^{\prime}\left(c_{l s 2}\right)\right]$. 
It is logical that a higher credit card interest rate will discourage people from borrowing and instead induce defaulting on the 401(k) loan. The effect of the expected rate of return in the first period is the same as discussed in the previous case: that is, a lower expected return would make people more likely to default on the $401(\mathrm{k})$ loans, as the opportunity cost of defaulting is smaller.

Now we can derive the complete expected utility difference model as:

$$
\begin{aligned}
\text { ExpectDiff }= & \left(1-P_{q}\right)\left[u\left(c^{*}{ }_{l q 1}\right)+\beta u\left(c^{*}{ }_{l q 2}\right)-u\left(c^{*}{ }_{c q 1}\right)-\beta u\left(c^{*}{ }_{c q 2}\right)\right]+ \\
& P_{q} \cdot \max \left\{u\left(c^{*}{ }_{l s 1}\right)+\beta u\left(c^{*}{ }_{l s 2}\right)-u\left(c^{*}{ }_{c s 1}\right)-\beta u\left(c^{*}{ }_{c s 2}\right), 0\right\},
\end{aligned}
$$

where $P_{q}$ is the probability of the participant having to leave her job. Notice that when the participant takes a 401(k) loan, even if she leaves her job, she can still choose to take a credit card loan to repay the $401(\mathrm{k})$ loan if it is more attractive than defaulting. Thus as long as the participant would be better off taking a $401(\mathrm{k})$ loan if she stays, her optimal choice is to take it without worrying about default.

From the discussion above, it is clear that a higher credit card interest rate would make people tend to take the $401(\mathrm{k})$ loan. Further, unless the participant is constrained by the maximum contribution amount of her $401(\mathrm{k})$ account, she would be better off by taking $401(\mathrm{k})$ loan if it has a lower interest rate. If she is constrained, the effect of the 401(k) loan interest rate could go either way. Another point worth noting is that, if the difference is close, a lower expected investment return rate during the loan period would make the 401(k) loan more favorable.

\section{Discussion}

We showed that a higher credit card interest rate and a lower 401(k) loan interest rate would have a positive effect on the likelihood of people borrowing from their 401(k) accounts. It is 
interesting that in a study of credit card rates, Gross and Souleles (2002) observe an average credit card interest rate of 16 percent, while the average $401(\mathrm{k})$ loan interest rate is 7.7 percent in our sample (about which we say more below). This large difference suggests that people might be thought more likely to borrow from their $401(\mathrm{k})$ accounts than from their credit cards. Nevertheless, Li and Smith (2008) report that many households persist in holding large credit card debt even when a plan loan would be cheaper. They suggest that financial advisers' negative opinions on taking 401(k) loans, along with peoples' 'mental accounting' mentality, i.e. treating 401(k) accounts primarily for retirement saving purposes rather than a part of the overall household balance sheet, may help explain why people do not make optimal use of 401(k) loans.

An additional reason that people might be cautious to take a plan loan is that $401(\mathrm{k})$ assets are only partly liquid. Each $401(\mathrm{k})$ plan has a minimum loan limit (typically $\$ 1,000$ ), and the law specifies that the maximum loan is $\$ 50,000$. More importantly, most plan sponsors allow participants to have only one loan outstanding at any time, and very few plans allow them to have more than three loans at once. Amromin (2003) suggests that restricted access to taxdeferred accounts may affect peoples' portfolio location and allocation decisions. As noted above, buffer-stock models predict that sensible borrowers might leave a precautionary buffer under the borrowing limit to allow for future consumption shocks, and this prediction is confirmed by Gross and Souleles (2002) in the credit card arena. In view of the fact that 401(k) borrowers are often constrained by the number of loans they can have at a time, it is thus not surprising that people might preserve the option to take a loan in the event of a potential future consumption shock. To examine this hypothesis in the 401(k) environment, we will test whether participants in 401(k) plans that allow more outstanding loans actually do take more loans, conditional on income and wealth. 
Our model also suggests that higher expected investment returns during the loan period would make taking a 401(k) loan more costly. Accordingly, when the economy is doing well and expected stock market returns are high, we should expect to see fewer 401(k) loans taken. Conversely, in a bear market, the opportunity cost of taking a 401(k) loan and defaulting might be lower. Combined with the tightening of credit and high job turnover rate, this might lead to more 401(k) loan taking and defaulting.

\section{Empirical Approach}

To test these hypotheses, we use a dataset from Vanguard on 401(k) pension plans with four years of participant loan and repayment records for employees covered by 959 different plans. Information available includes participant demographic and economic characteristics, along with plan characteristics from July 2004 to June 2008, along with a dataset recording all loans taken back to the 1980 s as well as the loans' status by end-June 2008. The analysis below focuses on active employees during the sample period permitted to take a loan.

Although loan interest rates vary by plan, most plans mark the plan borrowing rate to prime rate plus 1 percent. In Figure 1, we report the median loan interest rate in our sample compared to the prime rate over our period, and it is clear that the median loan interest rate tracks the prime rate very closely.

Figure 1 here

The average loan amount held during the sample period is slightly more than $\$ 8,300$. The median loan amount, though, is only $\$ 5,000$, showing that most are borrowing a relatively small amount of assets from their pension accounts. Figure 2 shows the distribution of loans over the period, which is much more skewed than the normal distribution. 
Figure 2 here

Participants with less than $\$ 100,000$ accumulated in their pension accounts can take a maximum of 50 percent of the account balance; the distribution is depicted in Figure 3. Virtually no one exploits the entire loan, and most of the time people take less than 20 percent of what they are permitted to take. Figure 4 shows what people borrow if they have accumulated $\$ 100,000$ or more and can only borrow up to $\$ 50,000$; only about 6-7 percent of borrowers eligible to take the maximum do so in any month.

Figures 3 and 4 here

Under the law, a regular plan loan must be repaid within five years. But participants may also take a principal residence loan to use for purchasing a home with a longer loan period, of between 15 - 30 years (depending on the plan). About 4 percent of all loans in our sample are principal residence loans, and as Figure 5 indicates, there is some seasonality in residential loans: the percentage is typically higher in spring and summer months, and it takes a dip during winter. Figure 5 here

Most plans charge annual maintenance fees when people take a loan. As long as the loan has not been fully repaid, the fee is generally charged annually. While the highest fee charged in our record is $\$ 45$ per year, the average annual fee is about $\$ 18$, a level that remains virtually unchanged during the period. Considering that the average loan amount is more than $\$ 8,000$, the annual fee is a relatively small cost.

Testable Hypotheses on Having a Loan. From the model, we hypothesize that people who are liquidity constrained are more likely to take 401(k) loans. Inasmuch as low-income people are more likely to be liquidity constrained (Gross and Souleles, 2002), we anticipate that lower-paid employees will also be more likely to have a loan outstanding. Age is likely to have a nonlinear 
effect on borrowing from the pension for several reasons. Love $(2006,2007)$ predicts that younger people who anticipate borrowing from their 401(k) plans in the future should boost their contributions, leading to higher balances; in this case, participants having higher balances would also be more likely to take a loan (controlling on other factors). To the extent that the typical lifecycle consumption profile is hump-shaped, peaking between 45 and 55 years of age (Gourinchas and Parker 2002; Browning and Crossley 2001), we would anticipate that people would have higher consumption needs during middle-age. Therefore controlling on other factors, we should see a middle-aged rise in 401(k) borrowing and level of loans outstanding. Holding constant age, longer plan tenure is likely to make the participant understand her plan better and hence be more likely to have a loan.

The empirical analysis also includes other participant-side factors including nonretirement wealth, to control on other assets available to the borrower. This is measured as the total nonretirement financial wealth by participant zipcode (IXI wealth ${ }^{2}$ ). We also know whether the participants' assets in the account result from contributions on the present job or are funds rolled over from a prior job. It is possible that participants might consider the rollover funds to be more their "own" money than accruals on a new job, in which case having rollover accounts might be positively associated with loan taking.

Several firm-side and plan-level effects are also evaluated. For instance, financial literacy could be important in boosting loan probabilities, and this may be more widespread among financial sector employees and workers in larger firms. People may be more cautious in industries and occupations with higher turnover rates. Plan features may also be important in anticipated ways. For instance, above we showed that lower plan interest rates would be

\footnotetext{
${ }^{2}$ IXI wealth code is generated by the IXI Corporation as a categorical measurement of household non-retirement financial assets based on zip code. We collapsed the original wealth classes into three groups: Poor (wealth $<\$ 7,280)$, Medium ( $\$ 7,280$ to $\$ 61,289)$, and Rich $(>\$ 61,289)$.
} 
expected to make borrowing more attractive; we predict more loans when plan interest rates are lower. We also argued that people may seek to maintain a precautionary buffer given a certain number of loans they are permitted to have. For this reason we examine whether allowing people to take only one loan versus more, makes them more cautious.

Testable Hypotheses on Loan Size. Given that someone takes a loan, the participant with a larger account balance should be able to take out a larger loan. While this should hold in general, we must take into account the fact that there is a legal cap of half the balance or $\$ 50,000$. Holding other factors constant, people with higher incomes will have higher expected lifetime incomes and therefore can afford to take out larger loans. Workers in plans that allow multiple loans may take smaller loans so as to preserve the precautionary buffer for the future. Age is likely to have a mixed impact, in that younger people are likely to have poorer credit histories and be more liquidity-constrained. On the other hand, since the lifecycle consumption profile is believed to be hump-shaped, it is also possible that middle-aged participants have higher consumption needs and so take bigger loans.

Participants with account balances less than $\$ 100,000$ are allowed to borrow up to 50 percent of their assets, while those with balances over $\$ 100,000$ will be constrained by the $\$ 50,000$ cap. We hypothesize that among the first group, people with lower account balances and lower household income are more likely to be constrained by the 50 percent cap. On the other hand, among those with account balances greater than $\$ 100,000$, we hypothesize that people with larger account balances are more likely to be constrained by the $\$ 50,000$ cap. Other factors should have the same effect on the fraction of the available loan taken, as on the size of the loan.

\section{Empirical Analysis}


Plan Borrowing. To explore the characteristics of those who borrow from their pensions, we use a multivariate logistic regression model as follows:

$$
\operatorname{Pr}\left(\operatorname{Loan}_{i, j, t}=1 \mid X_{i}, Z_{j}\right)=F\left(\alpha^{\prime} X_{i}+\beta^{\prime} Z_{j}+v_{i}+\eta_{j}+\tau_{t}+\varepsilon_{i, j, t}\right)
$$

where $F(x)=1 /(1+\exp (-x))$ and $\operatorname{Loan}_{i, j, t}$ is set to 1 if the participant has a loan outstanding in period $t$. The vector $X_{i}$ refers to employee characteristics including age, sex, tenure, wage, and household wealth. The vector $Z_{j}$ represents plan characteristics such as plan loan interest rate and number of outstanding loans allowed. We control for firm characteristics, including number of participants, plan average age, tenure and income, as well as industry. ${ }^{3}$ We also use the prime rate as an instrument to control for outside borrowing costs, and month dummies to control for seasonality.

We analyze the sample of 959 plans managed by Vanguard which allow loans, covering more than 2.3 million active participants during July 2004 - June 2008. Sample means of the independent variables appear in Column 1 of Table 1, while Column 1 of Table 2 shows marginal effects from Logit multivariate regressions. The probability of having a loan outstanding in any given month is about 19 percent, and as hypothesized, people with lower household income and lower non-retirement financial wealth whom we deem likely to be liquidity-constrained, are more prone to have $401(\mathrm{k})$ loans outstanding. We also find that people with lower account balances are more likely to have loans, and women are almost 1 percent more likely to have a loan outstanding than are men. Middle-age participants are more likely to have plan loans compared to their younger and older peers. Thus, holding other factors constant, those younger than age 25 are 6.7 percent less likely to have a loan compared to those age $35-45$;

\footnotetext{
${ }^{3}$ We have run these regressions while clustering at the plan level instead of controlling for firm characteristics and the results are very similar.
} 
people over age 55 are 6.6 percent less likely to have a loan. New hires, with fewer than two years of tenure, are 21.3 percent less likely to have a loan compared to those who have been in the plan for over eight years, while being web-registered makes one 6.8 percent more likely to have a loan, holding constant other factors. People who have rollover funds in their accounts are also more likely to take loans.

\section{Tables 1 and 2 here}

It is also interesting that participants in plans which permit multiple loans are more likely to have loans, consistent with predictions. We had also hypothesized that workers may retain a precautionary buffer given the number of plan loans allowed, and the empirical results are supportive: if the sponsor allows one more loan, this boosts loan probabilities by 1.6 percent. Further, lower loan interest rates are associated with more loans though the effect is relatively small: a 1 percentage point lower plan loan interest rate increases the probability of having a loan by only 0.3 percent.

Next we explore the characteristics of those who take a new loan, given that they are eligible to borrow from their accounts. Now the dependent variable indicates the probability that an eligible participant takes a new loan in month $t$. For a participant to be eligible to take a plan loan in a given month, she must have plan assets at least two times the minimum loan amount set by the plan; and not have already borrowed to the plan limit (in dollars and number of loans permitted). Column 2 of Table 1 provides variable means while Column 2 of Table 2 reports Logit marginal effects. Most factors have similar effects as above, though the magnitudes are much smaller since the probability of taking a new loan in a particular month is only 1.2 percent. Here the effect of the plan's interest rate on loans is not statistically significant. This may be because, unlike with credit card rates, lower plan loan rates give the borrower more to spend 
now at the cost of some accumulated retirement assets. And since plan loan interest rates are typically much lower than credit card rates, even if they do rise a bit, they are still well below rates on credit card loans. Additionally, some fraction of 401(k) borrowers may be undertaking a loan in an emergency, which could lead them to pay less attention to interest rates.

Accordingly, the empirical results largely support our hypotheses. Using household income and non-retirement financial wealth to indicate who is more liquidity-constrained, we find that the constrained subset is also more likely to tap into their 401(k) accounts using loans. Middle aged people (age 35-45) are also more likely to have 401(k) loans, consistent with previous empirical findings that a typical lifecycle consumption profile shows a hump during middle age. When more loans are permitted, people also take more loans, consistent with the precautionary motive prediction of buffer-stock models.

Loan Amounts. Next we examine the factors affecting loan amounts, focusing only on the subset of people who take a loan in each month. ${ }^{4}$ Besides the IRS regulation, plans may have their own more restrictive rules on how much one can borrow. To address this concern, we eliminate 41 plans that do not have any participant taking up to the $50 \%$ limit during the sample period. Column 3 of Table 1 reports sample means of independent variables and Table 3 shows OLS regression results where plan loan amounts are measured in natural logs. Here we see that middle-aged people are more likely to take larger loans, consistent with the hump-shaped lifetime consumption profile noted above. Plan tenure and web registration also have the same positive effects on loan size and proportion as they have on who has loans outstanding. It is interesting that, although women were more likely to have a loan in the prior table, men take larger loans, all else equal. The better off -- those with more non-retirement financial assets and

\footnotetext{
${ }^{4}$ Future work will explore additional statistical formulations.
} 
income -- are more likely to take larger loans. Previously we showed that these people are less likely to have a loan outstanding since they have more alternatives, so it is interesting that, conditional on taking a loan, they borrow more, perhaps because they can more readily repay the loan early in case of job change. As hypothesized, people with higher account balances take out higher loan amounts, which makes sense since those with higher balance have higher loan limits. Lower interest rates appear to boost the size of loans taken, though the effect is quite small. If a plan permits more loans, this reduces the size of each loan, supportive of the buffer stock view. Table 3 here

Another interesting question is who is constrained by the legal cap on loans. Table 4 examines the factors influencing whether people take the largest loan they can; column 1 examines people who hit any plan maximum, while column 2 refers to the 50 percent asset cap, and column 3 refers to the $\$ 50,000$ cap. Once again we see the the middle-age hump pattern: other factors constant, those age 35-44 are 3.8 percentage points more likely to be constrained by some cap than persons younger than age 25 . Younger people are also less constrained by the money cap than the percentage cap. Men are 1.8 percentage points more likely to hit the cap than women, more due to the percentage than the dollar limit. Those with higher income and more non-retirement financial assets are more likely to hit a cap: thus someone with over $\$ 61,300$ in non-retirement assets (people with high IXI wealth) is 3.6 percentage points more likely to take a maximum allowable loan, compared to someone with low non-retirement assets. The dollar limit is more likely to restrict higher earners and those with more nonfinancial assets, and unsurprisingly, those with lower account balances are more likely to be constrained by their lower percentage caps. Allowing one additional loan is predicted to reduce the probability of 
hitting the loan cap by 9.4 percentage points. Loan interest rates appear to be positively related to taking the maximum, but the effect is quite small.

Table 4 here

\section{Discussion and Conclusion}

This paper shows that 401(k) plans can be seen not only as a vehicle for retirement saving but also as a medium for precautionary saving that can help protect against income or consumption shocks. Our utility maximization model suggests that several factors will affect peoples' 401(k) loan demand, including liquidity constraints, plan interest rates, and plan features. Some find it puzzling that people do not seem to use $401(\mathrm{k})$ loans to repay more expensive outside debt, but we argue that people may wish to preserve a precautionary buffer for loans. We therefore predict that plans which allow multiple loans will see their participants take more loans.

Evidence on these hypotheses is provided using a Vanguard dataset on loan behavior in almost 1,000 employer 401(k) plans. While higher plan interest rates are associated with fewer loans, the effect is small: a one percentage point higher borrowing rate is associated with only a 0.3 percentage point lower probability of having a plan loan. Loan amounts are also fairly insensitive to interest rates, in that a one percentage point rise in the rate only decreases the size

of the loan by 0.4 percentage points. Evidently plan participants are not particularly responsive to borrowing costs. On the other hand, there is strong evidence of the buffer-stock aspect of plan loans: when a sponsor permits one additional loan, loan participation rises by 1.6 percentage points (from a base of 19 percentage points) and people that do borrow take smaller loans. 
We also detect a hump-shaped age profile among borrowers, where those age 35-45 are more likely to borrow -- and when they do, are more likely to take the maximum -- as compared to their younger and older counterparts. And using household income and non-retirement financial wealth to indicate who is more liquidity-constrained, we find that the constrained subset is also more likely to tap into its $401(\mathrm{k})$ accounts with loans. Yet those with more non-retirement financial assets and income take larger loans, more often at the legal limit. In sum, some plan borrowing is evidently driven by liquidity needs, while another portion is consistent with a rational life-cycle approach to retirement saving.

Future work will further explore the impact of macroeconomic factors on plan loans and defaults on 401(k) plan loans. Our model would predict that in a bear market, taking a 401(k) loan and defaulting on existing loans will become more prevalent, as the cost of borrowing and defaulting falls. 


\section{References}

Agnew, Julie, Pierluigi Balduzzi, and Annika Sunden (2003). "Portfolio Choice and Trading in a Large 401(k) Plan.” American Economic Review, 93(1): 193-215.

Ameriks, John, and Stephen Zeldes (2004). "How Do Household Portfolio Shares Vary with Age?" TIAA-CREF working paper.

Amromin, Gene (2003). "Household Portfolio Choices in Taxable and Tax-Deferred Accounts: Another Puzzle?" European Finance Review, 7: 547-582.

Attanasio, Orazio, and Martin Browning (1995). "Consumption over the Life Cycle and over the Business Cycle.” American Economic Review 85(5): 1118-1137.

Ayres, Ian, and Barry Nalebuff (2008). "Life-cycle Investing and Leverage: Buying Stock on Margin can Reduce Retirement Risk." NBER Working Paper No.14094, June 2008.

Browning, Martin, and Thomas Crossley (2001). "The Life-Cycle Model of Consumption and Saving." Journal of Economic Perspectives 15(3): 3-22.

Carroll, Chris (1997). "Buffer-Stock Saving and the Life-Cycle/Permanent Income Hypothesis." Quarterly Journal of Economics 112(1): 1-55.

Choi, James, David Laibson, and Brigitte Madrian (2004). "Plan Design and 401(k) Savings Outcomes." National Tax Journal Forum on Pensions.

Choi, James, David Laibson, Brigitte Madrian, and Andrew Metrick (2001). "For Better or For Worse: Default Effects and 401(k) Savings Behavior.” NBER working paper No. 8651.

Deaton, Angus (1991). "Saving and Liquidity Constraints.” Econometrica, LIX (1991): 12211248.

GAO Report to the Chairman, Special Committee on Aging, and the Honorable Judd Gregg, U.S. Senate (1997). “401(k) Pension Plans - Loan Provisions Enhance Participation but May Affect Income Security for Some.” Washington, DC: GAO.

Gourinchas, Pierre-Olivier, and Jonathan Parker (2002). "Consumption Over the Life Cycle." Econometrica 70: 47-89.

Gross, David, and Nicholas Souleles (2002). "Do Liquidity Constraints and Interest Rates Matter for Consumer Behavior? Evidence from Credit Card Data." Quarterly Journal of Economics 117(1): 149-185.

Holden, Sarah, and Jack Vanderhei (2001). "Contribution Behavior of 401(k) Plan Participants." ICI Perspective. Washington, D.C.: Investment Company Institute, 2001. 
Li, Geng, and Paul Smith (2008). "Borrowing from Yourself: 401(k) Loans and Household Balance Sheets." SSRN working paper 1222734, August 2008.

Love, David (2006). "Buffer Stock Saving in Retirement Accounts." Journal of Monetary Economics, 53: 1473-1492.

Love, David (2007). "What Can the Life-Cycle Model Tell Us About 401(k) Contributions and Participation?" Journal of Pension Economics and Finance, 6: 147-185.

Lusardi, Annamaria, and Olivia Mitchell (2008). "Planning and Financial Literacy: How do Women Fare?" American Economic Review P\&P 98:2, 413-417.

Ludvigson, Sydney (1999). "Consumption and Credit: A Model of Tiime-Varying Liquidity Constraints.” Review of Economics and Statistics, LXXXI (1999): 434-447.

Madrian, Brigitte, and Dennis Shea (2001). "The Power of Suggestion: Inertia in 401(k) Participation and Savings Behavior." Quarterly Journal of Economics, 116(4): 11491187.

Mitchell, Olivia, Gary Mottola, Stephen Utkus, and Takeshi Yamaguchi (2007). "The Dynamics of Lifecycle Investing in 401(k) Plans." Pension Research Council Working Paper 200728, October 2007.

Mitchell, Olivia, Stephen Utkus, and Stella Yang (2007). "Turning Workers into Savers? Incentives, Liquidity, and Choice in 401(k) Plan Design.” National Tax Journal Vol. LX, No.3, September 2007: 469-489.

Mitchell, Olivia, Stephen Utkus, and Stella Yang (2006). "Dimensions of 401(k) Plan Design." Restructuring Retirement Risks. Edited by David Blitzstein, Olivia Mitchell and Stephen Utkus. Oxford University Press: 186-203.

Munnell, Alicia, Annika Sunden, and Catherine Taylor (2000). "What Determines 401(k) Participation and Contributions?" Boston College CRR Working Paper No. 2000-12, December 2000.

Poterba, James, Steven Venti, and David Wise (1995). "Do 401(k) Contributions Crowd Out Other Personal Saving?” The Journal of Public Economics, 58: 1-32.

Reeves, Robert, and Pamela Villarreal (2008). “401(k) Loans = Retirement Insecurity.” National Center for Policy Analysis, Brief Analysis, No.615, April 2008.

Stephens, Melvin (2008). "The Consumption Response to Predictable Changes in Discretionary Income: Evidence from the Repayment of Vehicle Loans." The Review of Economics and Statistics, May 2008, 90(2): 241-252. 
Sunden, Annika, and Brian Surette (2000). "Household Borrowing From 401(k) Plans." Just the Facts on Retirement Issues No. 1. Center for Retirement Research, Boston College, June 2000: 1-4.

Tobin, James (1967). "Life-Cycle Savings and Balanced Growth.” Ten Economic Studies in the Tradition of Irving Fisher. Ed. William Fellner et al. New York: Wiley: 231-256.

U.S. Dept. of Labor (2007). "Private Pension Plan Bulletin: Abstract of 2005 Form 5500 Annual Reports." Washington, D.C.

Vanderhei, Jack, and Sarah Holden (2007). “401(k) Plan Asset Allocation, Account Balances, and Loan Activity in 2006.” EBRI Issue Brief, No.308: 1-39.

Yaari, Menachem (1965). "Uncertain Lifetime, Life Insuance, and the Theory of the Consumer." Review of Economic Studies 32(2): 137-150.

Zeldes, Stephen (1989). "Consumption and Liquidity Constraints: An Empirical Investigation." Journal of Political Economy, 97: 305-346. 
Table 1. Sample Characteristics

\begin{tabular}{|c|c|c|c|}
\hline Variable & $\begin{array}{c}\text { Mean of } \\
\text { Active Participants } \\
\end{array}$ & $\begin{array}{c}\text { Mean of } \\
\text { Active Participants } \\
\text { Eligible to take a } \\
\text { Loan } \\
\end{array}$ & $\begin{array}{c}\text { Mean of } \\
\text { Active Participants } \\
\text { who take a loan } \\
\end{array}$ \\
\hline Age (Year) & 43.5 & 44.5 & 41.2 \\
\hline Age $<25(\%)$ & 0.03 & 0.02 & 0.03 \\
\hline Age $25-35(\%)$ & 0.2 & 0.18 & 0.25 \\
\hline Age $35-45(\%)$ & 0.28 & 0.28 & 0.34 \\
\hline Age 45-55 (\%) & 0.31 & 0.32 & 0.29 \\
\hline Age $\geq 55(\%)$ & 0.17 & 0.19 & 0.1 \\
\hline Web Registered & 0.57 & 0.60 & 0.71 \\
\hline Plan Tenure (Years) & 7.99 & 8.55 & 7.76 \\
\hline Male & 0.48 & 0.51 & 0.44 \\
\hline Ln Household Income (\$) & 11.12 & 11.18 & 11 \\
\hline Low IXI Wealth Index (\%) & 0.46 & 0.42 & 0.61 \\
\hline Medium IXI Wealth Index (\%) & 0.32 & 0.33 & 0.29 \\
\hline High IXI Wealth Index (\%) & 0.22 & 0.25 & 0.1 \\
\hline Account Balance (\$) & 78,548 & 93,561 & 48,448 \\
\hline \# Plan Participants/1000 & 17.0 & 17.2 & 18 \\
\hline Rollover Flag (\%) & 0.10 & 0.12 & 0.09 \\
\hline Loan Interest Rate (\%) & 7.70 & 7.69 & 7.56 \\
\hline \# Loans Allowed & 1.60 & 1.66 & 1.8 \\
\hline $\begin{array}{l}\text { \# Plans } \\
\text { \# Observations }\end{array}$ & $\begin{array}{c}959 \\
62,141,010\end{array}$ & $\begin{array}{c}959 \\
46,207,312\end{array}$ & $\begin{array}{c}918 \\
537,316\end{array}$ \\
\hline
\end{tabular}

Note: This table reports mean sample characteristics. Column 1 shows means for all active participants of 959 plans (July 2004-June 2008); Column 2 shows means for those are eligible to take a 401(k) loan at a given month during the same period. Column 3 shows means for all active participants of the larger set of 918 plans who took a loan in each month during the period. Web registered is set to 1 if a participant has web access to her account, and 0 otherwise; plan tenure measures the period of time since the participant has joined the plan; household income index is a categorical variable that measures annual household income. IXI wealth codes are used to indicate wealth bands where Low IXI wealth is set to 1 if the household non-retirement wealth is $<\$ 7,280$, Medium IXI wealth is set to 1 if the household nonretirement wealth lies between $\$ 7,280$ and $\$ 61,289$, and High IXI wealth is set to 1 if the household nonretirement wealth is $>\$ 61,289$; Account balance refers to the dollar value of assets accumulated in the participant's retirement account; number of participants denotes the average number of participants in each plan divided by 1,000. Rollover flag is set to 1 if the participant has rollover funds from her previous retirement account in her current account; the loan interest rate is the interest rate applied to borrowing from the 401(k) plan; and number of loans allowed is the average number of loans taken by a participant in the plan. 
Table 2. Multinomial Logit Determinants of the Probability of Having a Loan Outstanding and Taking a New Loan (Marginal Effects reported)

\begin{tabular}{|c|c|c|}
\hline Variable & Who has an outstanding loan? & Who takes a loan? \\
\hline Age <25 (\%) & $-0.0666^{\star \star \star}$ & $-0.0017^{\star \star \star}$ \\
\hline Age $25-35(\%)$ & $-0.0180^{\star \star *}$ & $-0.0008^{\star \star \star}$ \\
\hline Age 45-55 (\%) & $-0.0163^{\star \star *}$ & $-0.0011^{\star \star \star}$ \\
\hline Age $\geq 55(\%)$ & $-0.0660^{\star \star \star}$ & $-0.0039 * \star \star$ \\
\hline Male & $-0.0089^{* \star *}$ & $-0.0007^{\star \star \star}$ \\
\hline Plan tenure $<2$ years & $-0.2131^{\star \star *}$ & $-0.0053^{\star \star \star}$ \\
\hline 2 years $\leq$ plan tenure $<4$ years & $-0.1286^{\star \star \star}$ & $-0.0027^{\star \star *}$ \\
\hline 4 years $\leq$ plan tenure $<6$ years & $-0.0708^{\star \star *}$ & $-0.0011^{\star \star \star}$ \\
\hline 6 years $\leq$ plan tenure $<8$ years & $-0.0378^{\star \star \star}$ & $-0.0005^{\star \star \star}$ \\
\hline HHIncomelndex $<45,000$ & $0.0732^{\star \star \star}$ & $0.0042^{\star \star \star}$ \\
\hline $45,000 \leq \mathrm{HHIncomelndex}<87,500$ & $0.0385^{\star \star \star}$ & $0.0019 * \star \star$ \\
\hline Ln Account balance & $-0.0032^{\star * *}$ & $-0.0005^{\star \star \star}$ \\
\hline Medium IXI wealth (\%) & $-0.0586^{\star \star *}$ & $-0.0032^{\star \star \star}$ \\
\hline High IXI wealth (\%) & $-0.1081^{\star \star \star}$ & $-0.0057^{\star \star \star}$ \\
\hline Web registered & $0.0683^{\star \star \star}$ & $0.0047^{\star \star \star}$ \\
\hline Rollover flag (\%) & $0.0018^{\star * *}$ & $-0.0007^{\star \star *}$ \\
\hline \# loans allowed & $0.0162^{\star \star \star}$ & $0.0016^{\star \star \star}$ \\
\hline Loan interest rate (\%) & $-0.0029 * \star \star$ & 0.0000 \\
\hline \# Observations & $62,141,010$ & $46,207,312$ \\
\hline Mean of Dependent Variable & 0.1890 & 0.0121 \\
\hline R-squared & 0.4212 & 0.7181 \\
\hline
\end{tabular}

Note: This table reports marginal effects from a multinomial Logit regression model. Column 1 shows the effects on the probability of having a loan in a given month, equal to 1 if the participant has a loan outstanding at month $t$, and 0 otherwise. Column 2 shows the effects on the probability of taking a loan in a given month. Marginal effects of Ln Account balance, Number of loans allowed, and Loan interest rate refer to a change in the dependent variable if, respectively, the person's balance increased by $\$ 10,000$; the number of loans allowed increased by 1; or the loan interest rate increased by 1 percentage point. We use the 35-45 age group as the reference age; the $\geq 8$ years tenure group as the reference tenure; the $\geq \$ 87,500$ household income group as the reference; Low IXI wealth for reference wealth. The natural $\log$ of the account balances is used; if the account balance is less than $\$ 1$, the log account balance is set to 0 . Models also control for firm-side average characteristics, industry, month, prime rate, and missing values of independent variables are dummied. $* * *, * * *$ denotes $10 \%, 5 \%, 1 \%$ significance levels, respectively. 
Table 3. Determinants of Loan Size (OLS Coefficients)

\begin{tabular}{|c|c|}
\hline Variable & Who takes a large loan? \\
\hline Age <25 (\%) & $-0.1823^{\star \star \star}$ \\
\hline Age $25-35(\%)$ & $-0.0494^{\star \star \star}$ \\
\hline Age 45-55 (\%) & $-0.0515^{\star \star \star}$ \\
\hline Age $\geq 55(\%)$ & $-0.1234^{\star \star \star}$ \\
\hline Male & $0.0336^{\star \star \star}$ \\
\hline Plan tenure $<2$ years & $-0.0721^{\star \star \star}$ \\
\hline 2 years $\leq$ plan tenure $<4$ years & $-0.0336^{\star \star \star}$ \\
\hline 4 years $\leq$ plan tenure $<6$ years & $0.0444^{\star \star \star}$ \\
\hline 6 years $\leq$ plan tenure $<8$ years & $0.0710^{\star \star \star}$ \\
\hline HHIncomelndex $<45,000$ & $-0.0663^{\star \star \star}$ \\
\hline $45,000 \leq \mathrm{HHIncomelndex}<87,500$ & $-0.0306^{\star \star \star}$ \\
\hline Ln Account balance & $0.6091^{\star \star \star}$ \\
\hline Medium IXI wealth (\%) & $0.0317^{\star \star \star}$ \\
\hline High IXI wealth (\%) & $0.0722^{\star * *}$ \\
\hline Web registered & $0.0861^{* * *}$ \\
\hline Rollover flag (\%) & 0.0049 \\
\hline \# loans allowed & 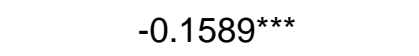 \\
\hline Loan interest rate (\%) & $0.0155^{\star \star \star}$ \\
\hline \# Observations & 537,316 \\
\hline Mean of Dependent Variable & 8.52 \\
\hline R-squared & 0.6211 \\
\hline
\end{tabular}

Note: The dependent variable is the natural log of the dollar amount borrowed, set to 0 if loan amount is less than $\$ 1$. See Table 2 for further definitions. 
Table 4. Determinants of the Probability of Taking a Maximum Loan (OLS Coefficients)

\begin{tabular}{|c|c|c|c|}
\hline Variable & Loan at Either Cap & $\begin{array}{c}\text { Loan at } \\
50 \% \text { Cap }\end{array}$ & Loan at $\$ 50 \mathrm{~K}$ Cap \\
\hline Age $<25(\%)$ & $-0.0377^{\star \star \star}$ & $-0.0499 * * \star$ & $-0.0718^{\star \star \star}$ \\
\hline Age $25-35$ (\%) & $-0.0089 * \star \star$ & $-0.0125^{\star \star \star}$ & $0.0317^{\star \star \star}$ \\
\hline Age $45-55(\%)$ & $-0.0034^{\star \star \star}$ & $-0.0075^{\star \star \star}$ & $-0.0268^{\star \star \star}$ \\
\hline Age $\geq 55(\%)$ & $-0.0073^{\star \star \star}$ & $-0.0237^{\star \star \star}$ & $-0.0208^{\star * *}$ \\
\hline Male & $0.0177^{\star \star \star}$ & $0.0164^{\star \star \star}$ & $0.0077^{\star \star \star}$ \\
\hline Plan tenure $<2$ years & $-0.0177^{\star \star \star}$ & $-0.0395^{\star \star \star}$ & $0.0789 * \star *$ \\
\hline 2 years $\leq$ plan tenure $<4$ years & $-0.0626^{\star \star \star}$ & $-0.0689 * \star \star$ & $0.0345^{\star \star}$ \\
\hline 4 years $\leq$ plan tenure $<6$ years & $-0.0329 * \star \star$ & $-0.0298 * \star \star$ & $0.0397^{\star \star \star}$ \\
\hline 6 years $\leq$ plan tenure $<8$ years & $-0.0177^{\star \star \star}$ & $-0.0115^{\star \star \star}$ & $0.0398^{\star \star \star}$ \\
\hline HHIncomelndex $<45,000$ & $-0.0247^{\star \star \star}$ & $-0.0257^{* \star *}$ & $-0.0078^{\star \star *}$ \\
\hline $45,000 \leq \mathrm{HH}$ Incomelndex $<87,500$ & $-0.0200 * \star \star$ & $-0.0154^{\star \star \star}$ & $-0.0128^{\star * *}$ \\
\hline Ln Account balance & $-0.0832^{\star \star \star}$ & $-0.1082^{\star \star \star}$ & $0.0595^{\star \star \star}$ \\
\hline Medium IXI wealth (\%) & $0.0080^{\star \star \star}$ & $0.0076^{\star \star \star}$ & $0.0095^{\star \star \star}$ \\
\hline High IXI wealth (\%) & $0.0357^{\star \star *}$ & $0.0196^{\star * *}$ & $0.0450 * * *$ \\
\hline Web registered & $0.0219 * * *$ & $0.0244^{\star \star \star}$ & $0.0053^{\star *}$ \\
\hline Rollover flag (\%) & -0.0003 & -0.0019 & $0.0096^{\star \star \star}$ \\
\hline \# loans allowed & $-0.0936^{\star \star \star}$ & $-0.1031^{* * *}$ & $-0.0372^{\star \star \star}$ \\
\hline Loan interest rate (\%) & $0.0066^{\star \star \star}$ & $0.0098^{\star \star \star}$ & -0.0007 \\
\hline \# Observations & 537,316 & 469,556 & 67,760 \\
\hline Mean of Dependent Variable & 0.1687 & 0,1832 & 0.0687 \\
\hline R-squared & 0.1254 & 0.1366 & 0.0585 \\
\hline
\end{tabular}

Note: The dependent variable in Column 1 is the probability of a loan being constrained, equal to 1 if the loan hits either the $50 \%$ of balance or $\$ 50,000$ cap. Column 2 examines the probability of a loan being constrained by only the $50 \%$ cap and Column 3 refers to a loan being constrained by the $\$ 50,000$ cap. For other variable definitions see Table 2 . 
Figure 1. Plot of Median Loan Interest Rates versus Prime Rate

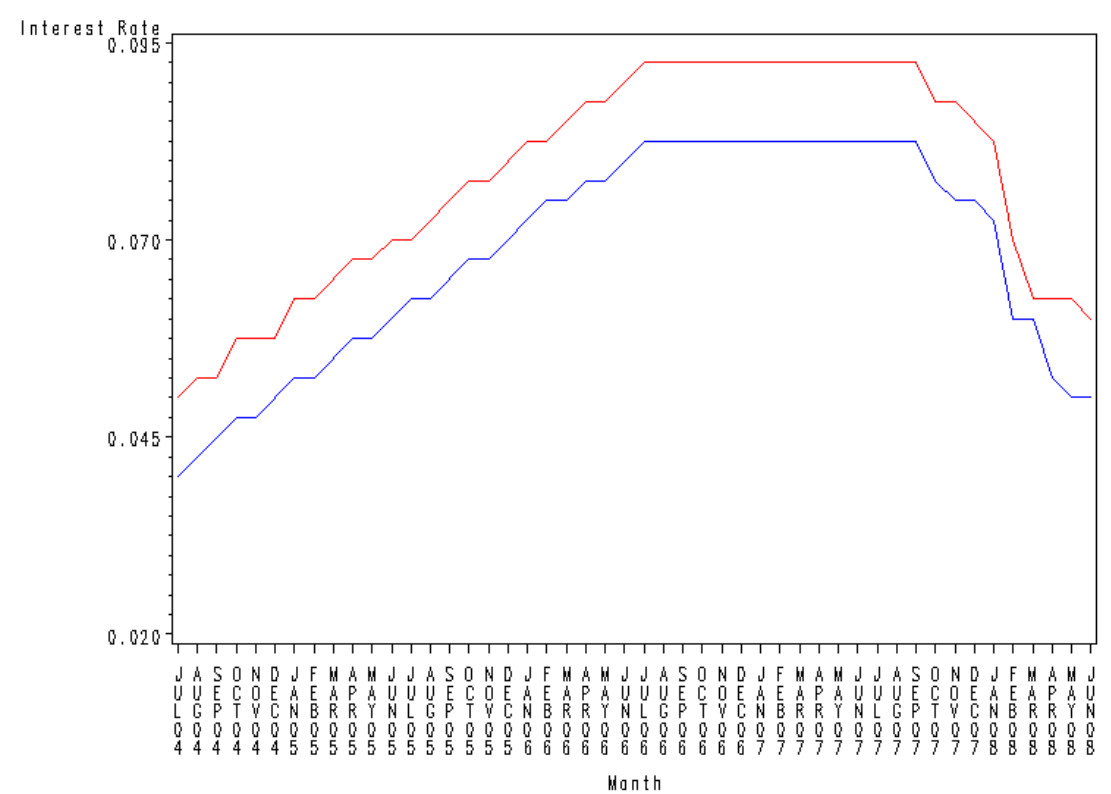

Note: Median Loan Interest Rate in Red, Prime Rate in Blue

Figure 2. Comparing the Distribution of New Loan Amounts and the Normal Distribution

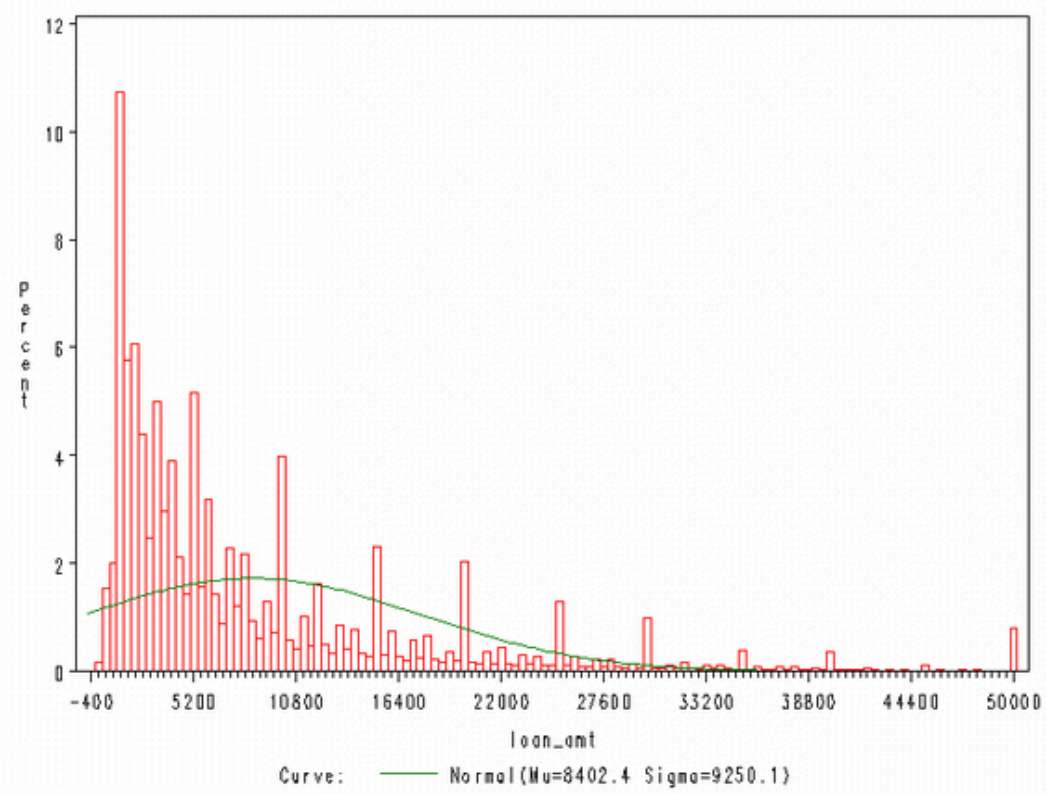


Figure 3. Percentage of Borrowers Taking Half their Account Balances

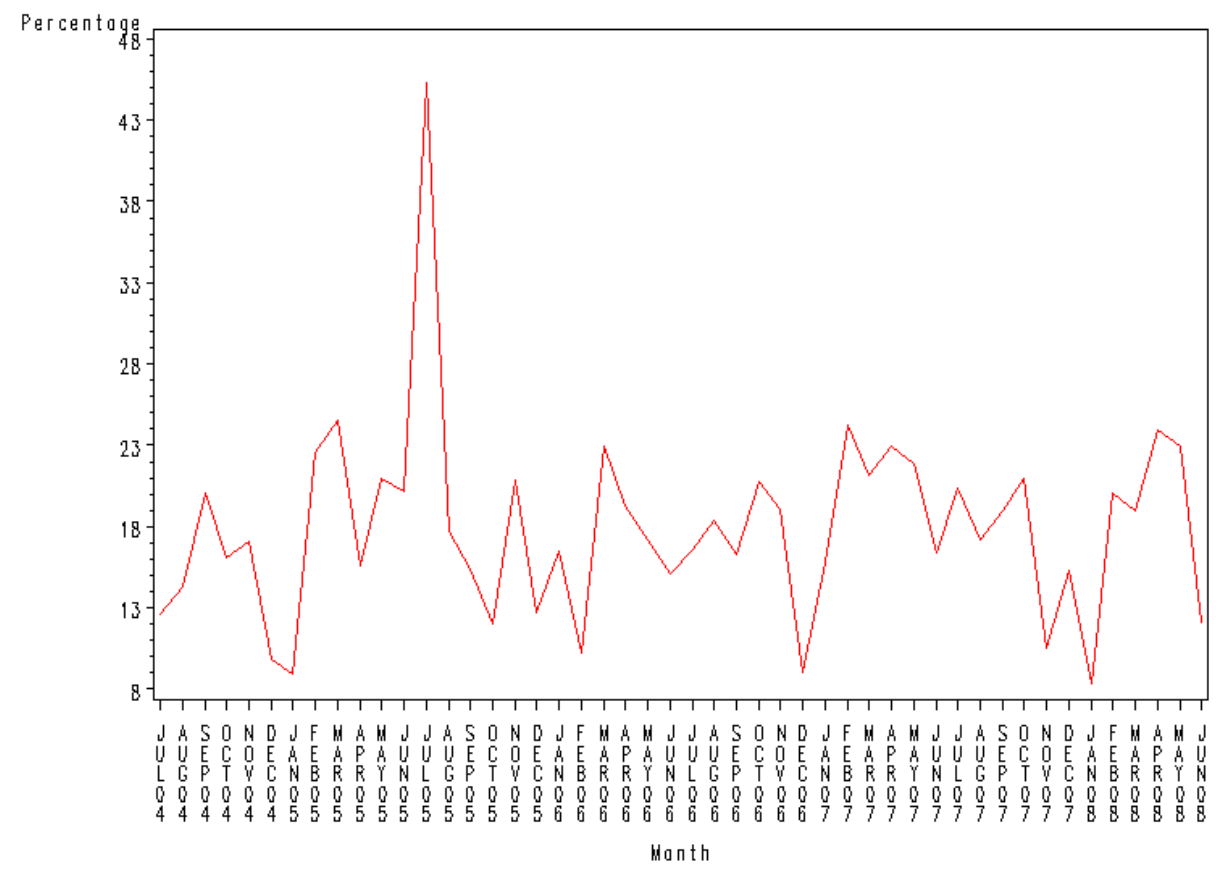

Figure 4. Percentage of Borrowers with Accounts of $\geq \$ \mathbf{1 0 0 , 0 0 0}$, and Who Take Loans of $\$ 50,000$

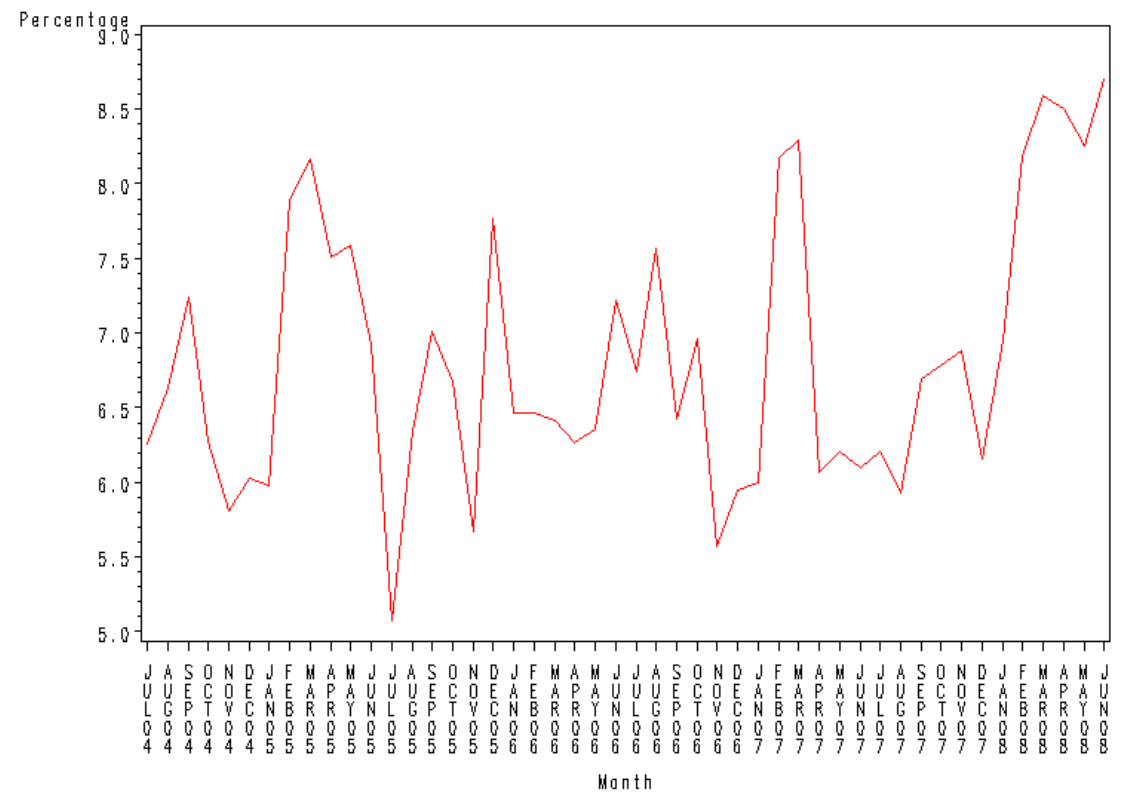


Figure 5. Percentage of Principal Residence Loans

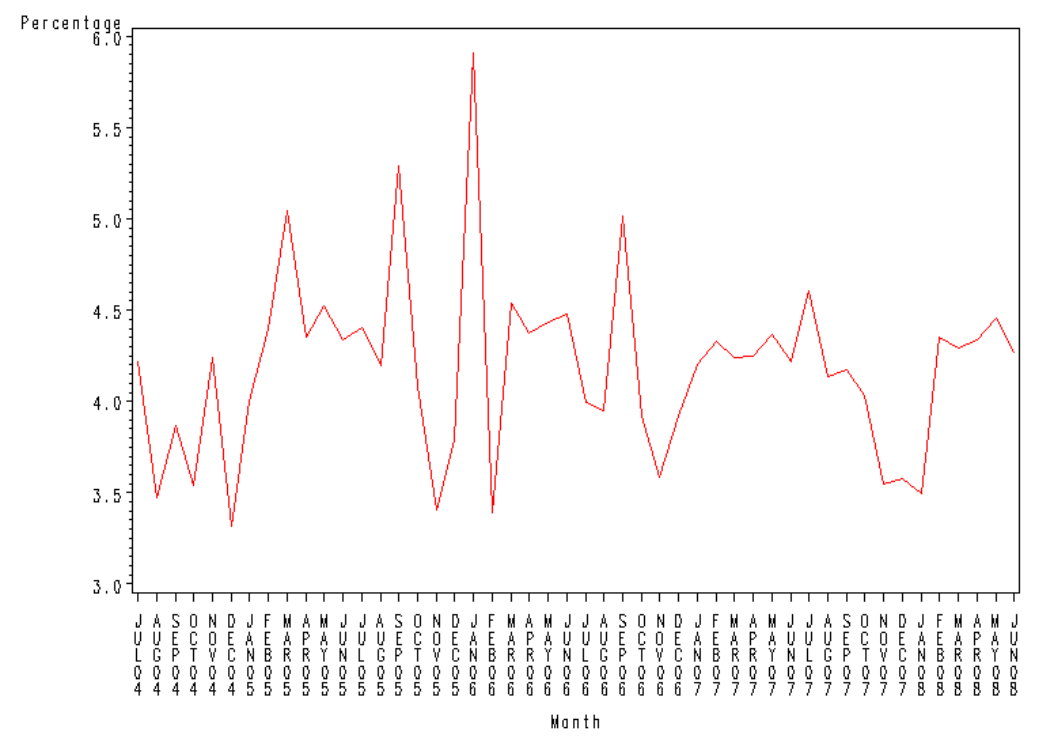

